\title{
The Role and Priorities of International Development Agencies to Democratic Governments' towards Education and Research in Africa: Educationists Perspective
}

\author{
Abdul-Kahar Adam* \\ Faculty of Management, University of Education, Ghana \\ Submission: July 20, 2018; Published: September 25, 2018 \\ "Corresponding author: Abdul-Kahar Adam, University of Education, Box 25, Winneba, Central Region, Ghana, Email: aka11@live.co.uk
}

\begin{abstract}
Education and Research is eminent to every economic advancement and development, i.e. how many resources and management decisions are taking nationally or as constitution mandates for government organizational operations. Hence, the main objective of this study is to evaluate both national and international policy framework in education and research on Africa from the IMF, World Bank, EU, OECD, World Vision International, UNESCO, UN, UNICEF, Getfund and the Scholarship Secretariat. The essence of this study is to review the challenges faced by Africa Democratic Governments in a short change of staggering education and research delivery policies and systems, hence, confounding the development of specific educational and research policies. This is to establish scholarship challenges at the advance stage of nation building where access to scholarship or government sponsorship at national level is poorly managed by delivery. These test three hypotheses such as H1: whether there is a relationship of International Development Agencies' policies, support more of education and research in Ghana as far as national HR development is concerned. H2: there is positive relationship between IDA to Public Administration (government) as recipient of supports. H3: there is positive significance of Public Administration (government) in targeting and executing Education and Research work.

Keywords: Donor management; International development agencies; Education and research; Global issues; Government; Public administration; Governance issues; Human resource Development issues
\end{abstract}

\section{Introduction}

The ultimate objective is to examine the roles and priorities of the International Development Agencies or organisations in education and research to African countries. And the research question is how good, or important such supports given to African governments, projects the growth of African continent? The essence of this study is to review the challenges faced by Africa Democratic Governments in a short change of staggering education and research delivery policies and systems, hence, confounding the development of specific educational and research policies. This is to establish scholarship challenges at the advance stage of nation building where access to scholarship or government sponsorship at national level is poorly managed by delivery.

Human Resource Management Troubles in Education Sector

Teaching staff absenteeism is due to low pay, the brain drains of qualified teachers from the teaching profession and informal user fees being charged, according to UNICEF. UNICEF has reported that real pay levels of public sector employees are falling, and it is further, reviewed at the recent IMF report which, shows that most African countries were being advised by the IMF to cut public sector wage bills in 2009 to 2011 [1].

\section{Academic Research Citation Indexing within African Context}

It is further stated that Sub-Saharan Africa has been very successful in research output and citation impact. Regions such as Southern and East Africa has improved their average quality of research output because it is now above the world average (i.e. normalized to 1). But about the West and Central Africa have nearly doubled their share of articles published globally and even though, their citation impact has not increased and remained relatively constant. More to this, is that, Africa's research capacity improvements have been closely tied to the high levels of international collaborations, that is, between African based researchers and those in Western countries [2,3]. It has revealed that over $70 \%$ of all research publications from Southern and East Africa have been co-authored with an international collaborator [4]. Also, they stated that "collaboration and working with 
Western researchers is one way for Africa to improve its research capacity and sending researchers abroad or welcoming outside researchers to Africa is another highly effective enabling tactic." The report found out that 'transitory researchers', that is, "those that spend less than two years in Africa or abroad, are far more productive and on average produce research of a higher impact research than researchers who have not had the opportunity to perform research outside of the continent" [4].

It is however recommended that while African authors have nearly doubled by sharing their articles over the past decade, it is hoped that the returns could be many times greater over the next decade if awareness of usage and research capacity are done in a collaborative and integrated manner by African institutions via access programs and publishers. Elsevier, since 2001, has been deeply engaged in programs to foster the growth of the African science community and support to African researchers to develop and enhance their research output and quality. Elsevier is a founding publisher of Research4Life, which is a public private partnership in tackling access of research in developing countries. Elsevier supplies over a quarter of " 44,000 books, journals and databases available to doctors, researchers and policymakers in Africa, and across more than 100 developing countries." With the Elsevier Foundation's Innovative Libraries in Developing Countries Program, they provided annual grants totalling $\$ 300,000$ donated to projects that build infrastructure, improve information literacy, repositories, and provide training to boost overall usage of Research4Life resources in Africa and beyond [4].

The Government Function as an Organisation in Nation Development

\section{New Public Administration Policy Systems and Management}

The public services must always respond to important requirements and the needs concerning the higher level of citizens' satisfaction of a nation [5]. All what these existing and previous literature talks about is New Public Administration (NPA) and New Public Management (NPM) and with these, it deliberates on the issues relating to World Bank, IMF, EU and so on, their overall global policy implementations on the third world countries - Africa. The existing literature researched, concentrated more on developmental agencies and Donor partners work for African countries and has few discussions on the history of Public Administration in the developed world. New Public Management (NPM) reforms in the advanced countries happens in the era of Structural Adjustment Programmes (SAP), a process which was driven by a combination of economic, social, political and technological factors of service delivery in responds only to satisfy external players like the World Bank, IMF, EU, USA, OECD etc and not from the total will of people per se (Doe 2005). According to (Doe 2005), he stated that Ghana has not been matured through any recognisable technocratic, systematic, or policy-making approach in the past decades or since independence, except that it had, but just a mimicked kind of public service administration and management practices through coercion/force/pressure from the developed countries and the International Development Agencies.

\section{Public Sector Administration to Boost Organisational Development}

Even, civil servants are developed into a lethargic and passive body whereby their functions are disconnected from the citizens and have no interest in adopting an active role in the service of the state [6]. Governance is a broad term that includes values and practices such as legality, justice, trust in laws and institutions, efficiency, responsible budgeting, management of human resources and crisis management [6]. Notwithstanding, the same existing literature talks about the challenges involve in the delivery of good governance in the public sector of economies. And the problem is, has the citizens have say in the governance process, or when it comes to establishing policies and programmes, how often have they been consulted and in what manner and channel? Are the people happy with the way government establishes and delivers its programmes?

\section{Problem with Internal Generated Funds in Africa to Support Government Policies}

According to Annan [7], noted the need for curbing the menace of corruption and weak governance together with international tax avoidance and evasion, which are the main crucial matters that affect democratic governments in Africa, and this makes it impossible for people of Africa to benefit from their continent vast natural mineral resources and wealth. At the forum, it was stated that the African continent is losing more through illicit or unsolicited financial outflows than it receives in aid and foreign direct investments as the general view is perceived by World of Business indicators and reports [8]. What the forum found in their report was that trade mispricing or losses are associated with the misrepresentation of export and import price values by African dealers, together with other illicit outflows which cost the continent \$38.4-billion and \$25-billion respectively between 2008 and 2010. Mr. Kofi Annan advocated for the G20 a rule-based global system on tax transparency to be developed. "All foreign-owned companies should be required to disclose the ultimate beneficiaries of their profits," [7].

\section{The IMF}

This situation continues due to the ideologies entrenched in the field of economics and are taught in schools about monetarism. Even countries without under the IMF strict loan programs, they are still faced with IMF restrictions, if not, there should be investment in higher public sectors of work but due to the IMF biases in ideological sense that underpin their conventional monetary policies makes it difficult for such countries to flourish. It is obvious that many current finance ministries and central banks officials who have gone to school in the last 26-36 years have largely been taught one thing, and one thing only, which is that the only "prudent" and "sound" 


\section{Annals of Social Sciences \& Management studies}

option for fiscal and monetary policies is the very conservative one favoured by the Reagan and Thatcher governments, which were suddenly introduced in the school of monetarism within neoclassical economics. Because of this assertion, all other viable options which is actual and that would allow for higher public investment have subsequently been dismissed as "imprudent" and "unsound". Therefore, the problem is much more bigger than just the IMF because even if a country does not currently have an IMF loan program, but it means its fiscal and monetary policies are still likely to be subjected to the same sharp right-wing turn that has been taken into the economics profession for over 36 years ago, from which it's yet to recover or find solutions to Kyrili and Martin [9] (Figure 1).

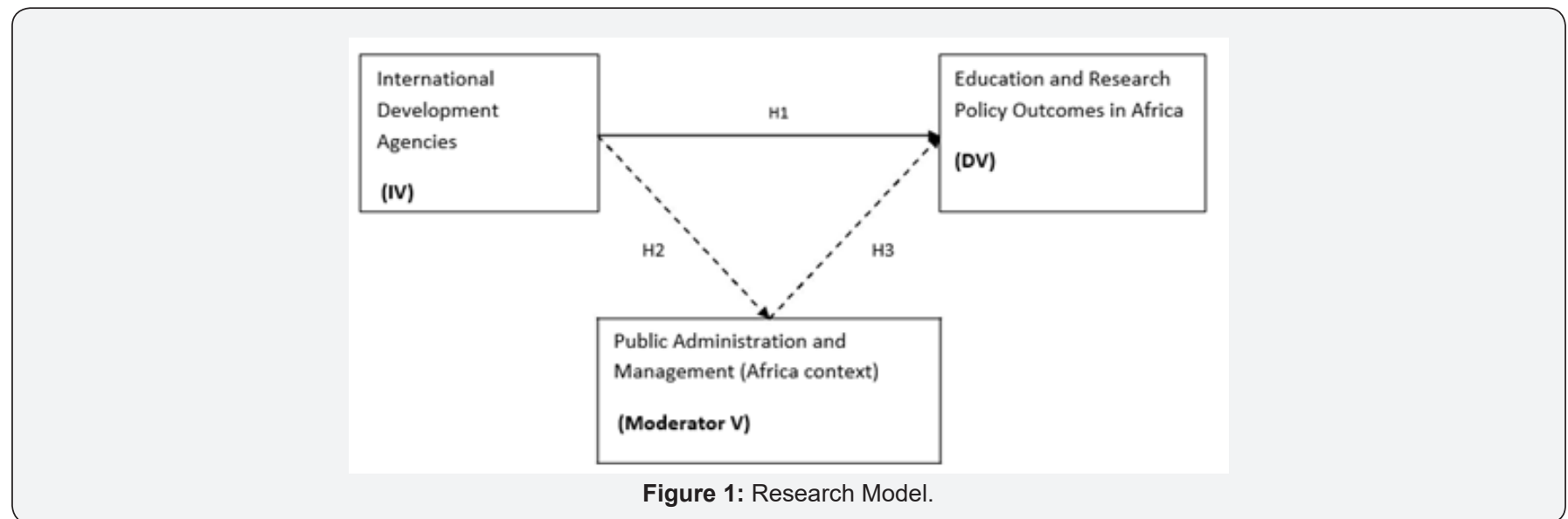

Research Methods

Respondents of Educationists
Professor
$0 \%$
$\begin{aligned} & \text { PHD } \\ & \text { Diploma 8\% } \\ & 13 \% \\ & \text { Masters } \\ & 20 \% \\ & \begin{array}{l}\text { Degree } \\ 59 \%\end{array}\end{aligned}$

This is an empirical study and therefore, its sampling technique has been non-probability sampling, hence, a convenience technique was adopted through as a questionnaire administered through social media WhatsApp platforms and emails. Out of this process 5 participants responses are been used for this data analysis and discussion and of which conclusion is drawn. Educationists were the target participants for this research and therefore a convenience sample response of 54 participants has been sorted. The questionnaire was designed using Google Forms as online survey tool. Therefore, a future probability study is required to ascertain the efficiency and significance of this topic as another way of supporting these current data findings. This includes reliability testing with SmartPLS, and the use of Fuzzy Delphi Method - shows mathematically uncertain phenomena within the environment [10]. Excel spreadsheet was used for the pie chart of respondents (Figure 2).
Table 1: No. of Responses.

\begin{tabular}{|c|c|}
\hline \multicolumn{2}{|c|}{ Respondents } \\
\hline Level of Education & No. of Responses \\
\hline Professor & 0 \\
\hline PHD & 4 \\
\hline Masters & 11 \\
\hline Degree & 32 \\
\hline Diploma & 7 \\
\hline Total & 54 \\
\hline
\end{tabular}

From Table 1 and chart represents the target respondents of this research totalling 54 responses. Out of this number, $59 \%$ were degree holders, 20\% were Masters' holders, $13 \%$ were Diploma holders, and $8 \%$ were $\mathrm{PhD}$ holders. Whereas no Professor gets to respond to the questionnaire due to may be the use of the social media systems and platforms such as whatsApp of link and emails of the links been sent. But this also signifies that the target of this research has been achieved because all those participated can be classified as educationists (Figure 3).

\section{PLS Algorithm}

Table 2: Path Coefficient (Matrix).

\begin{tabular}{|c|c|c|c|}
\hline & Edu_Res & IDA & PubAdmin \\
\hline Edu_Res & & & \\
\hline IDA & 0.35 & & 0.649 \\
\hline PubAdmin & 0.17 & & \\
\hline
\end{tabular}

With the construct above shows the values of the factor loadings to each variable and the corresponding effects of the moderator variable and the dependant variable on the IDA as independent variable. In the blue indicates the $\mathrm{R}$ Squares whereas the arrows show the relationship effects that takes place 


\section{Annals of Social Sciences \& Management studies}

between the variables with regression rates (can be positive or negative). And so, by convention, path loadings should be above $0.70[11,12]$. For this research, none has dropped (Table 2). The path from IDA to Edu_Res is positive coefficient of 0.350 and IDA to PubAdmin is positive coefficient of 0.649 whereas, PubAdmin to Edu_Res is positive coefficient of 0.170 . These means that IDA to PubAmin as a moderator variable has stronger relationship than, as a moderator in executing or having a less final impact and effect towards Edu_Res. Path coefficients are standardized with weights which varies between -1 to +1 . Therefore, weights closet to 1 is the strongest coefficient path and weights close to 0 are the weakest coefficient path (Table 3).

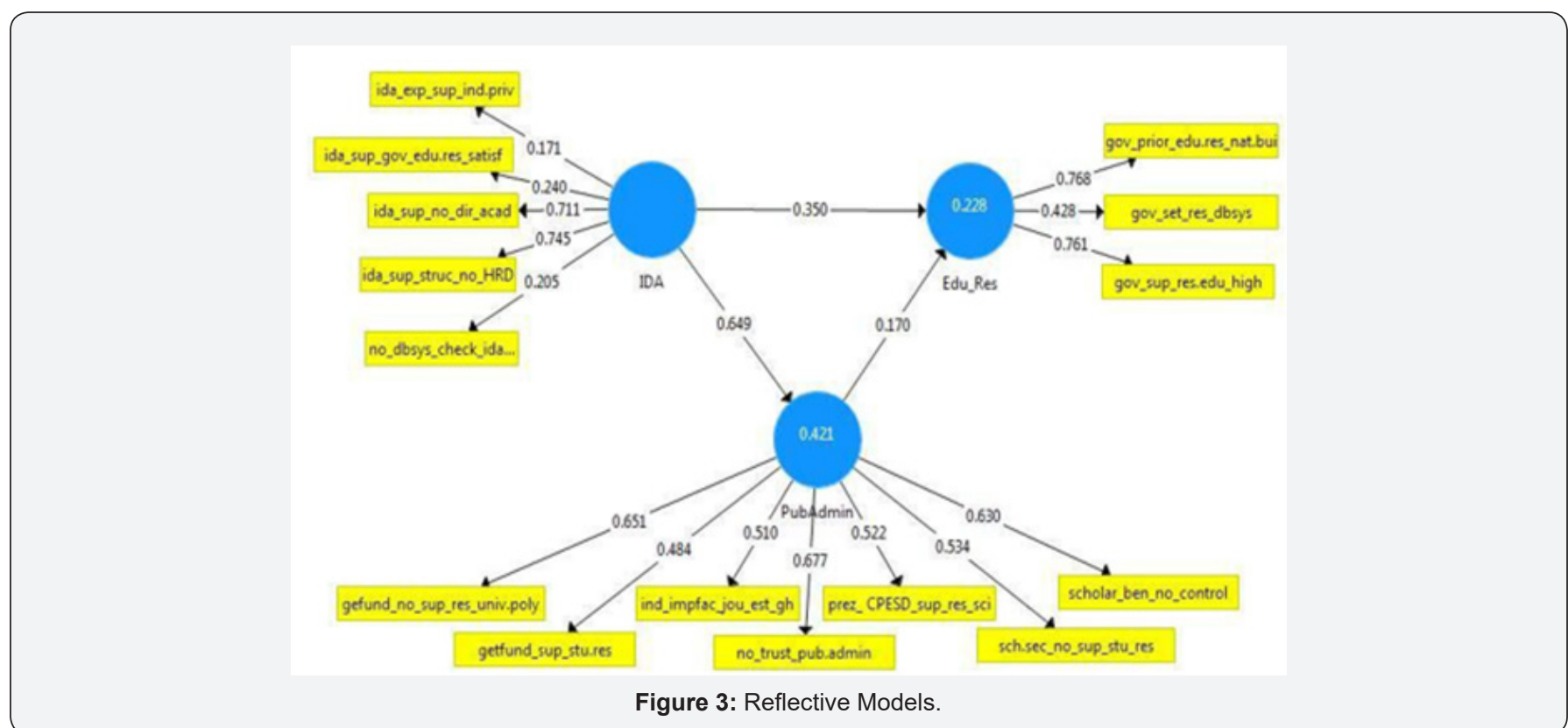

Table 3: $R$ Square (the coefficient of determination).

\begin{tabular}{|c|c|c|}
\hline & R Square & R Square Adjusted \\
\hline Edu_Res & 0.228 & 0.198 \\
\hline PubAdmin & 0.421 & 0.409 \\
\hline
\end{tabular}

The above means that about $23 \%$ of the variance in Edu_Res is explained in the model (i.e. between IDA and Edu_Res). Also, about $42 \%$ of the variance in PubAdmin is explained in the model from IDA to PubAdmin as a moderator variable towards the independent variable Edu_Res at $23 \%$ model explained all together. Hence, there is an indirect effect within this model as IDA to PubAdmin to Edu_Res. Chin [13], Höck \& Ringle [14] describes results above the cut-offs $0.67,0.33$ and 0.19 to be "substantial", "moderate" and "weak" respectively (Tables 4-6) (Figure 4).

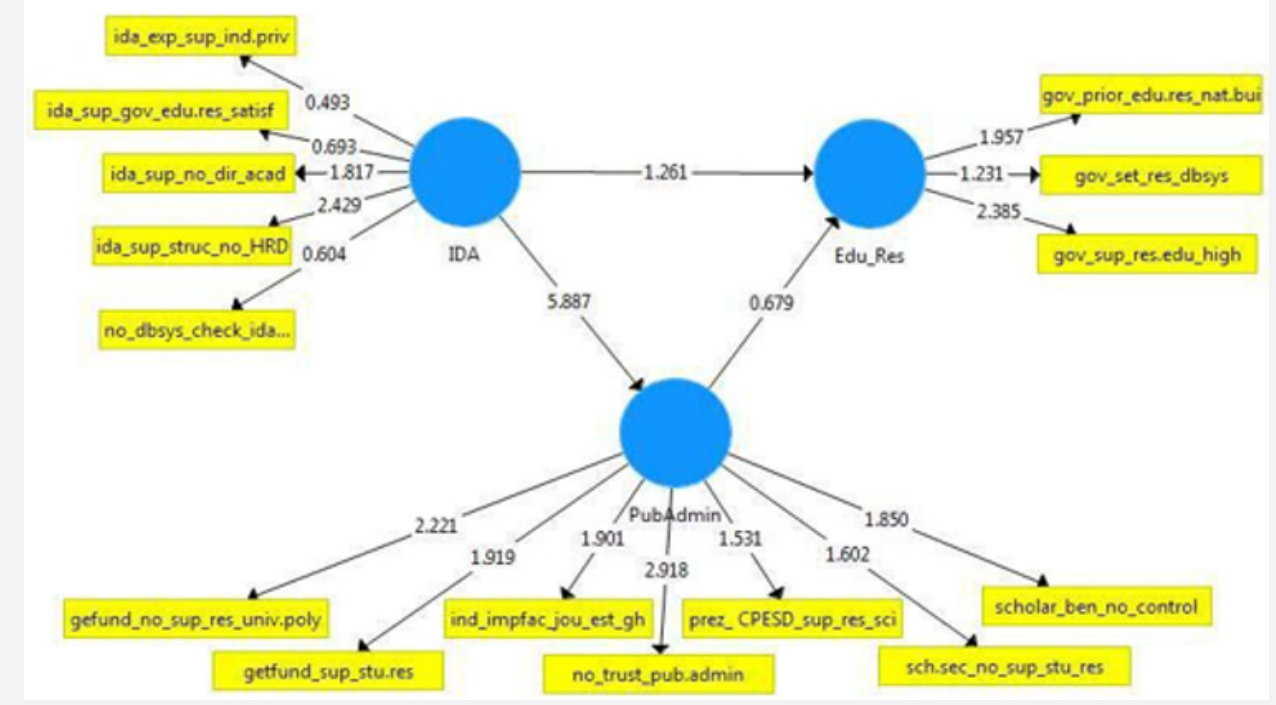

Figure 4: Significance Coefficients. 
Annals of Social Sciences \& Management studies

Table 4: $f$ Square.

\begin{tabular}{|c|c|c|c|}
\hline & Edu_Res & IDA & PubAdmin \\
\hline Edu_Res & & & \\
\hline IDA & 0.092 & & 0.726 \\
\hline PubAdmin & 0.022 & & \\
\hline
\end{tabular}

Table 5: Fornell-Larcker Criterion.

\begin{tabular}{|c|c|c|c|}
\hline & Edu_Res & IDA & PubAdmin \\
\hline Edu_Res & 0.671 & & \\
\hline IDA & 0.46 & 0.488 & \\
\hline PubAdmin & 0.397 & 0.649 & 0.577 \\
\hline
\end{tabular}

Table 6: Construct Reliability and Validity.

\begin{tabular}{|c|c|c|c|c|}
\hline & $\begin{array}{c}\text { Cronbach's } \\
\text { Alpha }\end{array}$ & Rho_A & $\begin{array}{c}\text { Com } \\
\text { Reliability } \\
\text { posite }\end{array}$ & $\begin{array}{c}\text { Average } \\
\text { Variance } \\
\text { Extracted (AVE) }\end{array}$ \\
\hline Edu_Res & 0.353 & 0.404 & 0.699 & 0.451 \\
\hline IDA & -0.011 & 0.186 & 0.53 & 0.238 \\
\hline PubAdmin & 0.663 & 0.671 & 0.775 & 0.333 \\
\hline
\end{tabular}

\section{Composite Reliability}

Table 7: Mean, STDEV, T-Values, P-Values.

\begin{tabular}{|c|c|c|c|c|c|}
\hline & $\begin{array}{c}\text { Sample } \\
\text { (0) }\end{array}$ & $\begin{array}{c}\text { Sample } \\
\text { Mean (M) }\end{array}$ & $\begin{array}{c}\text { Standard } \\
\text { Deviation } \\
\text { (STDEV) }\end{array}$ & $\begin{array}{c}\mathbf{T} \\
\text { statistics } \\
\mathbf{( | \mathbf { O } /} \\
\text { STDEV) }\end{array}$ & $\begin{array}{c}\mathbf{P} \\
\text { Values }\end{array}$ \\
\hline $\begin{array}{c}\text { IDA->Edu_- } \\
\text { Res }\end{array}$ & 0.35 & 0.325 & 0.277 & 1.261 & 0.208 \\
\hline $\begin{array}{c}\text { IDA- } \\
\text { >PubAdmin }\end{array}$ & 0.649 & 0.686 & 0.11 & 5.887 & 0 \\
\hline $\begin{array}{c}\text { PubAdmin- } \\
\text { >Edu- Res }\end{array}$ & 0.17 & 0.249 & 0.25 & 0.679 & 0.497 \\
\hline
\end{tabular}

Table 8: Confidence Intervals.

\begin{tabular}{|c|c|c|c|c|}
\hline & $\begin{array}{c}\text { Original } \\
\text { Sample (0) }\end{array}$ & $\begin{array}{c}\text { Sample } \\
\text { Mean (M) }\end{array}$ & $\mathbf{2 . 5 0 \%}$ & $\mathbf{9 7 . 5 0 \%}$ \\
\hline $\begin{array}{c}\text { IDA->Edu_ } \\
\text { Res }\end{array}$ & 0.35 & 0.325 & -0.442 & 0.701 \\
\hline $\begin{array}{c}\text { IDA- } \\
>\text { PubAdmin }\end{array}$ & 0.649 & 0.686 & 0.43 & 0.858 \\
\hline $\begin{array}{c}\text { PubAdmin- } \\
\text { >Edu- Res }\end{array}$ & 0.17 & 0.249 & -0.239 & 0.803 \\
\hline
\end{tabular}

From Table 7 shows that there is reliability at Edu_Res and PubAdmin as an adequate model whereas IDA is very weak composite (Table 7). It is noted that, all t-values above 1.96 are significant at 0.05 levels [12]. Therefore, according to the $t$ values in the above table show that IDA to Edu_Res is not significant as well as PubAdmin to Edu_Res is also not significant. But the $t$ value of IDA to PubAdmin is very significant at 5.887. More so, according to the p-value at p>0.05 means that IDA to Edu_Res is insignificant at $p=0.208$ because it supports the fact that IDA support for Edu_Res is not IDA major policy. Also, IDA to PubAdmin (government) is significant in the sense that $p=0.000$, hence, it confirms that IDA only has a policy of given support to the PubAdmin (government) and not probably support any other development or project. Finally, PubAdmin (government) to Edu_ Res is weak evidence since $\mathrm{p}<0.5$ which means that PubAdmin in turn does not really use the support received by IDA's to build or support Edu_Res (Table 8). The above shows that CI at $97.5 \%$ level of IDA to Edu_Res is between, $-44 \%$ to $70 \%$. Also, the CI of $97.5 \%$ level of IDA to PubAdmin (government) is within $43 \%$ and $86 \%$, whereas the CI of $97.5 \%$ level of PubAdmin to Edu_Res is between $-24 \%$ to $80 \%$. This simply means that the confidence level of this data is IDA to PubAdmin (Table 9).

Table 9: Confidence Intervals Bias Corrected.

\begin{tabular}{|c|c|c|c|c|c|}
\hline & Original & Sample & Bias & $\mathbf{2 . 5 \%}$ & \\
\hline & Sample & Mean (M) & & & \\
\hline & $(\mathbf{0})$ & & & -0.634 & 0.675 \\
\hline IDA->Edu_Res & 0.350 & 0.325 & -0.024 & 0.119 & 0.791 \\
\hline IDA->PubAdmin & 0.649 & 0.686 & 0.037 & -0.512 & 0.572 \\
\hline PubAdmin->Edu- & 0.170 & 0.249 & 0.080 & & \\
\hline Res & & & & & \\
\hline
\end{tabular}

To determine certainties, CI bias is corrected as above as IDA to Edu_Res as a bias of almost - $2 \%$ with a corresponding $97.5 \%$ confidence level corrected between, $-63 \%$ to $68 \%$. Moreover, the bias of IDA to PubAdmin is positive $4 \%$ with a corresponding $97.5 \%$ confidence level corrected from $20 \%$ to $79 \%$. Meanwhile, PubAdmin to Edu_Res bias is 8\% with a corresponding $97.5 \%$ confidence level corrected as $-51 \%$ to $57 \%$ (Figure 5). From the above clearly shows that all the projects listed are lacking in the educational systems and operations of research in the educational curricular. Policies to support such projects are minimal in nature and hence, lack the implementation of such projects across board.

\section{Conclusion and Recommendation}

According to Power [15] we noted that fears has been expressed over the education and research in the $21^{\text {st }}$ century were countries in the global world would be more competitive and therefore, education must be a human right rather than been traded as a marketing commodity, where high prices would made impossible for the intelligent poor to benefit. Power said, "If we fail, I fear that our world will become increasingly unequal, competitive, polarised, conflicted and dangerous" [15]. Power [15], UNDP [16], report warned that anytime market prices goes too far and become dominance towards social and political motives, the outcomes, the opportunities and rewards 
of globalization expand unequally and inequitably and rather what we see happening is concentrating wealth and power provided to a selected group of people, corporations and nations, and marginalizing others, that is, if global opportunities are not shared better, then the failures in the last decades in growth of nations will continue. UNESCO [17], outlined significant changes that are needed to occur in pre-service teacher education programs as guidelines for future implementation, this is because there is the need to select and prepare a new generation of teachers to be equipped with the skills, knowledge and values to help their cultural differences and social disadvantages.

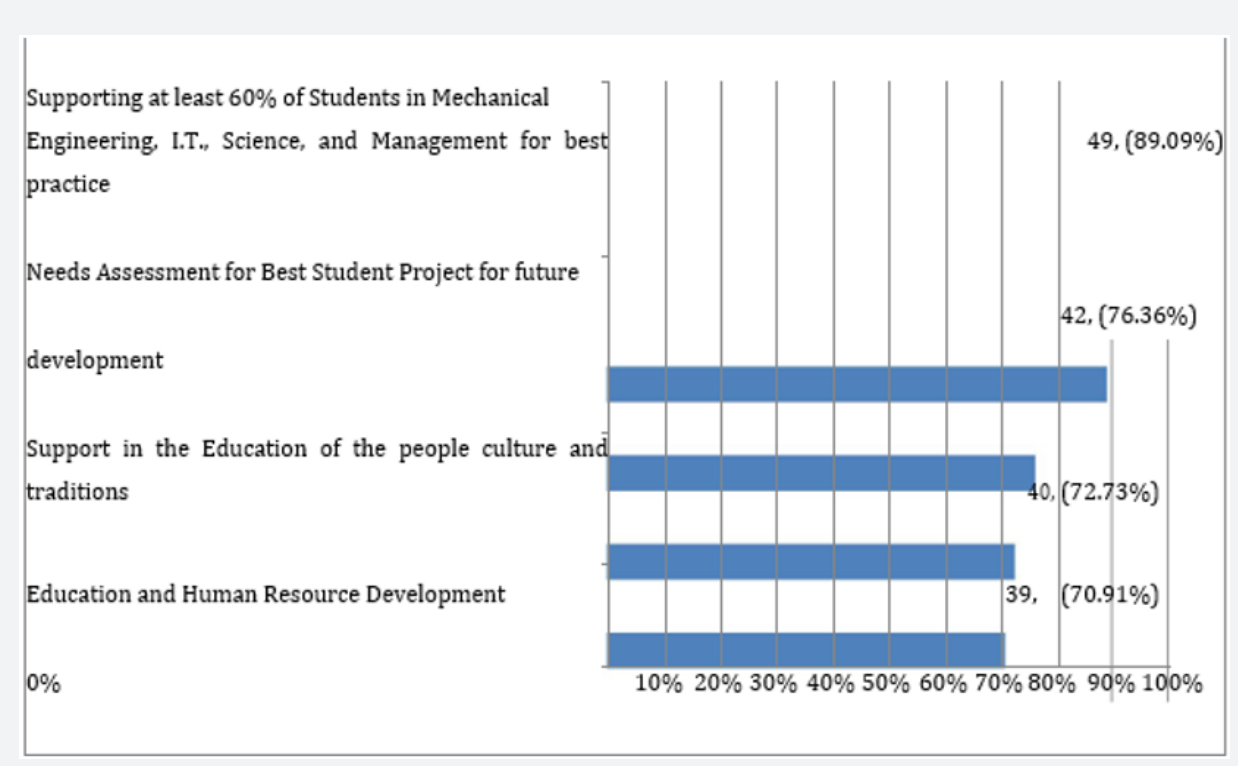

Figure 5: Projects Lacking in the Educational System.

The Western World political observers and leaders already judged African countries to be practicing democracy only in the beginning of the 1990s, and they have already concluded that unless African countries accept western ideas of practicing democracy, especially, formulated with conditionalities of donor countries including financial institutions, the future of Africa development is bound to be bleak [18]. It has been noted that the over reliance of African countries continuously on foreign aid only increased bilateral and multilateral aid agencies to influence their opportunities in policy making towards the African continent and these have been linked to donor supports being giving to African governments. For example, prescriptions for changes in both political and economic policies designed by African governments' such as education and research. Also, the new world created has interest and influence of the Western countries gained considerably greater advantage over African governments [19].

According to Doe (2005), he stated that Ghana has not been advanced in technology, systems, or policy-making approach in the past years. Since independence, Ghana only has a mimicked or funny kind of public service administration and management practices through coercion/force/pressure from the developed countries and the International Development Agencies. Under the path coefficient IDA to PubAmin as a moderator variable has stronger relationship than, as a moderator in executing or having a less final impact and effect towards Edu_Res. This explains the fact that International Development Agencies or organizations deals with the African governments than just directly donating or supporting in the Area of Education and Research needs of the country. There has been discriminant validity towards Education and Research. There is also reliability at Education and Research, and Public Administration as an adequate model whereas International Development Agencies has very weak composite towards Education and Research in general. According to the p-value at $p>0.05$ shows that IDA to Edu_Res is insignificant as in H1: IDA support for Edu_Res is not IDA major policy [20,21].

H2: IDA to PubAdmin (government) is significant because it confirms that IDA only has a policy of given support to the PubAdmin (government) and not probably support any other developmental project. H3: PubAdmin (government) to Edu_Res has weak evidence because PubAdmin in turn does not really use the supports it receives by IDA's to build or sponsor good Education and Research. H2: is even evident that the confidence level of these research findings is at IDA to PubAdmin. Therefore, based on the above conclusions, it is important for both the African governments and the international development agencies or organizations such as the IMF, World Bank, EU etc to move away from close door kind of policies and be more proactive in tackling educational needs as well as research development to enhance true development across sections of African economies. Hence, there must be proper transparency and accountability so that the people will feel the impact of IDA presents and their supports. In this case there may be the need for future study into the IDA policies implementation on African governments to include large population of probability sampling to contradict or confirm same. Projects that are lacking in the 
educational research area, within the curriculum of educational activities must be given proper attention by IDA and the Public Admin or the Central Governments. This will be the only best way to develop human capital for Africans and thereby improving on the governments' Human Resource Management policies as established.

\section{References}

1. UNICEF (2010) Prioritizing Expenditures for a Recovery with a Human Face: Results from a Rapid Desk Review of 86 Recent IMF Country Reports. Social and Economic Policy Working Briefs, UNICEF Policy and Practice.

2. Aucoin P (2012) New Political Governance in Westminster Systems: Impartial Public Administration and Management Performance at Risk, Governance: An International Journal of Policy, Administration, and Institutions, Wiley Periodicals, Inc. 25 (2): 177-199.

3. Aucoin P and Heintzman R (2000) The Dialectics of Accountability for Performance in Public Management Reform, International Review of Administrative Sciences 66 (1): 45-55.

4. Lan G, Kisjes I (2014) Study Assesses the State of Sub-Saharan Africa's Research Enterprise and Analyzes Areas for further Improvement.

5. Matei L, Matei A, Lazar CG (2016) Public service performance and good administration Socio-economic empirical evaluations. Procedia Economics and Finance 39: 335-338.

6. Ladi S (2008) Good Governance and Public Administration Reform in the Black Sea Economic Cooperation (BSEC) Member States. International Centre for Black Sea Studies, Multimedia Ltd, Greece.

7. Annan K (2013) Report: Corruption, weak governance costing Africa billions, The African Progress Panel Report at the World Economic Forum on Africa took place in Cape Town, Africa.

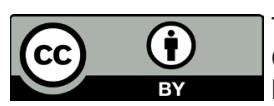

This work is licensed under Creative Commons Attribution 4.0 License DOI: 10.19080/ASM.2018.01.555571
8. Bratton M and Mattes R (2000) Support for Democracy in Africa Intrinsic or Instrumental? University of Chicago Press, USA.

9. Kyrili K, Martin M (2010) The hidden crisis: Armed conflict and education: Monitoring the impact of the financial crisis on national education financing: A cross country study.

10. Zadeh LA (1965) Fuzzy Sets. Information and control 8(3): 338-353.

11. Henseler J, Ringle CM, Sarstedt M (2012) Using Partial Least Squares Path Modelling in International Advertising Research: Basic Concepts and Recent Issues. Edward Elgar, USA. pp. 543.

12. Garson GD (2016) Partial Least Squares: Regression, and Structural Equation Models, Statistical Associates Blue Book Series. School of Public and International Affairs, North Carolina State University, USA.

13. Chin WW (1998) The partial least squares approach for structural equation Modelling. In: Cohen J, (Eds.), Statistical Power Analysis for the Behavioural Sciences. Lawrence Erlbaum, USA.

14. Höck M, Ringle CM (2006) Strategic networks in the software industry: An Empirical Analysis of the Value Continuum.

15. Power CN (2000) Global Trends in Education. International Education Journal 1(3): 152-163.

16. UNDP (1999) World Development Report.

17. UNESCO (1996) Learning: The Treasure Within.

18. Rawlings JJ (2008) Challenges for Democracy in Africa. Nigeria.

19. Kpundeh SJ (1992) Democratization in Africa: African Views African Voices, Panel on Issues in Democratization, National Research Council. National Academy Press, Washington, USA.

20. http://www.unesco.org/education/pdf/15_62.pdf

21. Sarstedt M, Henseler J, Ringle CM (2011) Multigroup Analysis in Partial Least Squares (PLS) Path Modelling: Alternative Methods and Empirical Results. Advances in International Marketing 22: 195-218.

\begin{tabular}{|l|}
\hline \multicolumn{1}{|c|}{ Your next submission with Juniper Publishers } \\
will reach you the below assets \\
- Quality Editorial service \\
- Swift Peer Review \\
- Reprints availability \\
- E-prints Service \\
- Manuscript Podcast for convenient understanding \\
- Global attainment for your research \\
- Manuscript accessibility in different formats \\
( Pdf, E-pub, Full Text, Audio) \\
- Unceasing customer service \\
Track the below URL for one-step submission \\
https://juniperpublishers.com/online-submission.php \\
\hline
\end{tabular}

